\title{
Chemical oxygen demand fractions of municipal wastewater for modeling of wastewater treatment
}

\author{
*I. Pasztor; P. Thury; J. Pulai \\ Department of Environmental Engineering and Chemical Technology, University of Pannonia, \\ Veszprem, Hungary \\ Received 15 March 2008; $\quad$ revised 17 July 2008; accepted 23 August 2008; avaLDble online 10 December 2008
}

\begin{abstract}
When a new wastewater treatment plant is being designed by computer simulation, detailed data about organic fractions of influent wastewater (measured as chemical oxygen demand) are usually not available, but knowledge of the typical ranges of these fractions is indispensable. The influent chemical oxygen demand fractions can substantially influence the results of simulation-based design such as reactor volumes, solids residence time, effluent quality, oxygen demand, sludge production, etc. This article attempts to give an overview of wastewater organic fractions as modeling parameters and presents new chemical oxygen demand fractionation results from Hungary. According to the data from literature, the ratio of chemical oxygen demand components in raw wastewater is very different and the average composition is as follows: Inert particulate $=17.1 \%$, slowly biodegradable $=$ $57.9 \%$, inert soluble $=7.8 \%$ and readily biodegradable $=17.5 \%$. The Hungarian wastewater samples were analyzed according to STOWA (Dutch foundation for applied water research) protocol and the obtained results were not much different from those of literature $($ inert particulate $=23.7 \%$, slowly biodegradable $=49.8 \%$, inert soluble $=4.6 \%$ and readily biodegradable $=21.9 \%$ ), but some typical characteristics were observed.
\end{abstract}

Key words: Simulation, activated sludge models, sewage, characterization

\section{INTRODUCTION}

Use of the activated sludge models (ASM) in wastewater treatment plant (WWTP) simulation is widespread. Nowadays, the design of activated sludge WWTPs is based on simulation studies instead of the empiric formulas.

\section{Base data availability for designers}

In the case of new WWTP design when wastewater samples are not available for characterization, the level of model calibration is quite low. In such cases only literature data, default values and assumptions can provide the base information needed to set influent characteristics and biokinetic parameters (Vanrolleghem et al., 2003). The assumed influent Chemical oxygen demand (COD), N, P fractions can substantially influence the results of simulation-based design such as reactor volumes, solids residence time, effluent quality, oxygen demand, recirculation rates, sludge production, etc. Many publications are available on wastewater characterization, but not a single review article on COD fractions can be found. That is why summarizing the published data on wastewater \*Corresponding Author Email: fapipa@yahoo.com Tel.:+36 3038107 15; Fax: +36 88578321 composition is important in design practice and thus in achieving accuracy in WWTP design.

\section{Division of organic matter}

Generally, influent N (ammonium, nitrate, total nitrogen) and $\mathrm{P}$ (orthophosphate, total phosphorous) fractions can be assessed easily because they are routinely measured in every WWTP. Moreover, characterization of nitrogen and phosphorous fractions is not necessary in as much detail as for COD because the major part of influent nitrogen is present in ammonia and most of the phosphorous occurs in orthophosphate form. In ASM1 and ASM3 models, the total influent COD $\left(\mathrm{COD}_{\mathrm{TOT}}\right)$ of the wastewater is divided into seven fractions and in ASM2 and ASM2d models into nine (Henze et al., 1987; 1995; 1999; 2000). The most important influent COD fractions, which are used as component variables in activated sludge models, are shown in Fig. 1.

\section{Determination of COD fractions}

Several methods have been developed for wastewater characterization, but the two most 


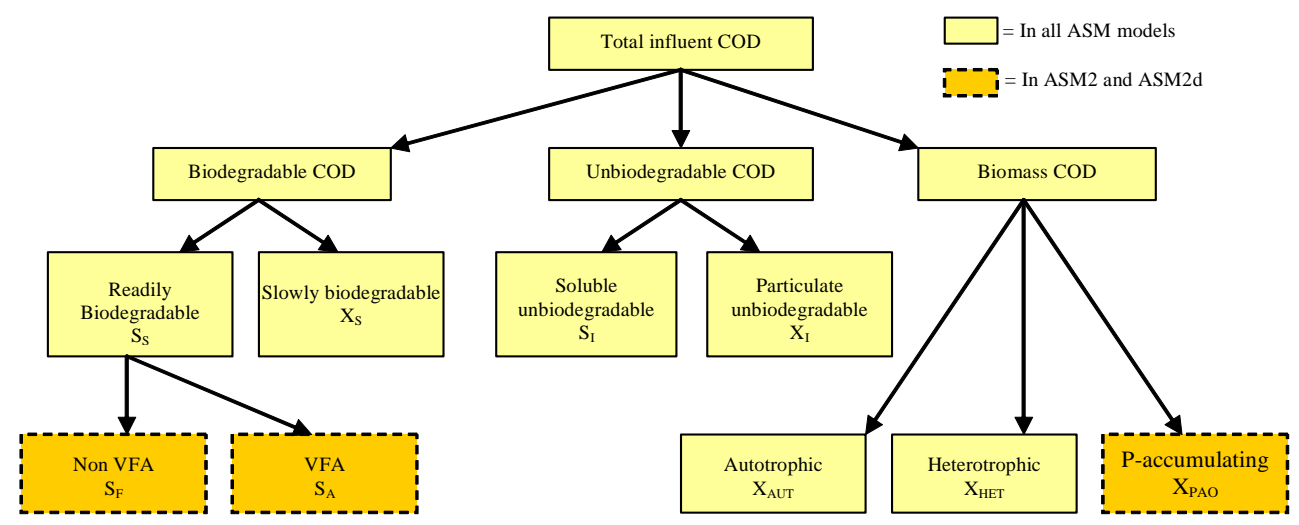

Fig. 1: Division of influent wastewaters into COD components in ASM model family

commonly used processes are the biological and physical-chemical characterizations. The biological or respirometric characterization method is based on the measurement of the biomass response during substrate degradation in either continuous flow or batch type experiment. The recorded utilization rate of the dissolved oxygen or nitrate (for denitrification potential) is closely related to the quality and quantity of available substrate in the system (Spanjers et al., 1995). This method needs experienced and skilled laboratory staff, specific experimental appliances and usually model-based interpretation. It may provide higher accuracy and is therefore more suitable for research studies. The physicochemical method is based on the assumption that COD fractions model can be separated by filtration and flocculation processes and that COD of the gained fractions is easily measurable by standard chemical methods (Mamais et al., 1993). The main problem of this process is that the filtration can not effectively separate readily and slowly biodegradable fractions because the colloidal (between soluble and particulate) matter may contribute to both fractions. The combined physicalchemical and biological method of STOWA (Dutch foundation for applied water research) includes both filtration and flocculation steps with COD and BOD measurements (Roeleveld and Loosdrecht, 2002). This method is quick and easy to use, but it completely neglects biomass fractions. Also, the information provided on Xi fraction could be false because the fraction is determined by the remainder in the last characterization step [inert particulate $\left(\mathrm{X}_{\mathrm{I}}\right)=\mathrm{COD}_{\text {тот }}{ }^{-}$ slowly biodegradable $\left(\mathrm{X}_{\mathrm{S}}\right)$ - readily biodegradable $\left(\mathrm{S}_{\mathrm{s}}\right)$ - inert soluble $\left(\mathrm{S}_{\mathrm{I}}\right)$ ]. The inaccuracies of the first determined fractions can be reflected in $\mathrm{X}_{\mathrm{I}}$ (Melcer $e t$ al., 2003). The simplicity and cheapness of this method make it suitable for new simulation users and consultants (Sin et al., 2005).

\section{MATERIALS AND METHODS}

The aim of this study was to collect and summarize the data of wastewater COD fractions from several countries, including Hungary and to provide default modeling parameters to WWTP designers. First, the wastewater characteristics of different countries were collected from literature and then their COD fractions were summarized separately as primary (settled) and raw wastewater data (Tables 1 and 2). Concurrently, COD fractions of the influent sewage of 11 Hungarian WWTPs were determined using the STOWA protocol treating municipal wastewater with only minimal industrial contribution (Roeleveld and Loosdrecht, 2002). Twenty-four-hour composite samples of influent wastewater were collected after screening, but before primary sedimentation or any kind of biological treatment. Final effluent samples were collected at the outlet of the secondary sedimentation tanks before disinfection. The capacities of examined WWTPs were between 100 and $15,000 \mathrm{~m}^{3} / \mathrm{d}$ with 12 $20 \mathrm{~d}$ solid retention time.

The main steps and theoretical formulas of COD fractionation

$\mathrm{S}_{\mathrm{I}}=90 \%$ of filtered $(0.45 \mu \mathrm{m})$ effluent COD; $\mathrm{S}_{\mathrm{S}}=$ Flocculated $\left(\mathrm{ZnSO}_{4}\right)$ and filtered $(0.45 \mu \mathrm{m})$ influent COD$\mathrm{S}_{\mathrm{I}} ; \mathrm{S}_{\mathrm{A}}=$ Measured by ionchromatography from influent sewage; $\mathrm{S}_{\mathrm{F}}=\mathrm{S}_{\mathrm{S}}-\mathrm{S}_{\mathrm{A}} ; \mathrm{X}_{\mathrm{S}}=\mathrm{BOI}_{\text {ULtтмAтE }}-\mathrm{S}_{\mathrm{S}} ;\left(\mathrm{X}_{\mathrm{I}}\right)=\mathrm{COD}_{\text {TOT }^{-}}$ $\mathrm{S}_{\mathrm{I}}-\mathrm{S}_{\mathrm{S}}-\mathrm{X}_{\mathrm{I}}$

Measurement of COD and BOD was carried out following standard methods. The measured influent COD fractions of the two examined WWTPs were validated by computer simulation which yielded good correlation. 


\section{RESULTS AND DISCUSSION}

Ranges of ASM COD fractions from design viewpoint Readily biodegradable substrate

$\left(\mathrm{S}_{\mathrm{S}}\right)$ is the most easily available COD fraction for heterotrophic microorganisms. The quantity of $\mathrm{S}_{\mathrm{S}}$ can be a determining factor for anaerobic and anoxic reactor volumes in model-based design because the processes of phosphate release and denitrification are very sensitive to the easily accessible substrate fractions.

According to scientific data, readily biodegradable substrate ranges between 3-35\% in raw wastewater and $14-57 \%$ in settled wastewater (Lesouef et al., 1992; Funamizu et al., 1997; Chachaut et al., 2005; Marquot et al., 2006). In ASM2 and ASM2d models, this component is divided into volatile fatty acids (VFA = acetic acid, propionic acid, butyric acid, etc.) and non-VFA components (alcohols, lower amino acids, simple carbohydrates) (Henze, 1992). The VFA fraction ranges between $0-8.8 \%$ in raw wastewater and $0-16 \%$ in primary wastewater (Henze, 1992; Henze et al., 1995; Satoh et al., 2000; Hydromantis, 2007).

\section{Slowly biodegradable substrate}

$\left(\mathrm{X}_{\mathrm{s}}\right)$ component comprises complex organic compounds which need to be hydrolyzed by extra cellular enzymes of bacteria prior to utilization. This component is usually made up of colloidal and suspended COD fractions. That is why it can not be separated from influent samples solely by physical separation. From the design point of view, this fraction usually has the highest oxygen demand and therefore it greatly influences the air flow required to aeration tank.

This component ranges between 28-74 \% in raw sewage and 24.5-65 \% in primary wastewater (Solfrank, 1988; Lesouef et al., 1992; Roeleveld and Loosdrecht, 2002; Marquot et al., 2006).

\section{Soluble unbiodegradable}

COD fraction $\left(\mathrm{S}_{\mathrm{I}}\right)$ can not be further biologically degraded in treatment plants and therefore the influent $\mathrm{S}_{\mathrm{I}}$ COD leaves the plant without any significant change in its concentration. Because of the soluble inert fraction of sewage, WWTPs treating strong municipal wastewaters or septic tank effluents $\left(\mathrm{COD}_{\mathrm{TOT}}>1500\right.$ $\mathrm{mg} / \mathrm{L}$ ) with even perfect carbon oxidation may find it hard to meet the strict COD effluent standards. $\mathrm{S}_{\mathrm{I}}$ fraction, relative to the $\mathrm{COD}_{\text {тот }}$, is in the range of $2-15 \%$ in raw wastewater and 3-14.3\% in primary sewage (Henze, 1992; Xu and Hultman, 1996; Satoh et al., 2000).

\section{Particulate unbiodegradable}

$\left(\mathrm{X}_{\mathrm{I}}\right)$ component is not degraded biologically during the treatment process and hence it can be removed only by clarification. From designers' point of view, this fraction significantly influences the quantity of primary and secondary sludge and therefore it determines the required dewatering and sludge treating capacity. Raw wastewater and primary wastewater contain 8-39\% and 4-20 \% X, respectively. (Ekama et al., 1986; Henze et al., 1987; Carucci et al., 1999; Roeleveld and Loosdrecht, 2002).

\section{Biomass COD}

In ASM2 and ASM2d models, bio mass is classified into three fractions: Heterotrophic biomass $\left(\mathrm{X}_{\mathrm{H}}\right)$; autotrophic biomass $\left(\mathrm{X}_{\mathrm{AUT}}\right)$ and phosphorous accumulating microorganisms $\left(\mathrm{X}_{\mathrm{PAO}}\right)$. COD fractions of $\mathrm{X}_{\mathrm{AUT}}$ and $\mathrm{X}_{\mathrm{PAO}}$ are generally not measured; their fractions in percent of $\mathrm{COD}_{\text {тот }}$ are assumed to be about $1 \%$ or less. Because of the low growth rate of autotrophic and phosphate accumulating organisms, their biomass fractions have to be considered in the modeled influent, otherwise, they can be washed out in high-loaded systems (Roeleveld and Loosdrecht, 2002).

Heterotrophic biomass may constitute a significant fraction in wastewater COD. The range of $X_{H}$ is $7-20 \%$ in raw wastewater and 3.5-25\% in primary settling tank effluent (Solfrank, 1988; Henze, 1992; Lesouef et al., 1992; Gernaey and Jorgensen, 2004).

\section{Summary of foreign and Hungarian COD fractions}

Data about the COD fractions of different studies were summarized separately as fractions of raw wastewater (Table 1) and settled wastewater (Table 2).

The results of Hungarian raw wastewater measurement are presented in Table 3. When the biomass fraction is not determined separately, as is often the case, $\mathrm{X}_{\mathrm{H}}$ can be measured as $\mathrm{X}_{\mathrm{S}}$. Therefore, every Table has a ' $\mathrm{X}_{\mathrm{S}}\left(+\mathrm{X}_{\mathrm{H}}\right)$ ' column in which the biomass fraction is included in the 'slowly biodegradable organic fraction' to facilitate comparison of the data. The measured Hungarian average COD fractions in raw wastewater $\left(X_{I}=23.7 \%, X_{S}=49.8 \%, S_{I}=4.6 \%, S_{S}=21.9 \%\right)$ are not much different from the corresponding values found in the literature of foreign countries $\left(X_{I}=17.1 \%, X_{s}=57.9 \%\right.$, $\mathrm{S}_{\mathrm{I}}=7.8 \%, \mathrm{~S}_{\mathrm{S}}=17.5 \%$ ) (Figs. 2 and 3). The values of COD fractions as seen in the foreign publications are very diverse and belong to the Hungary. Nevertheless, some typical characteristics can be observed in the values 
Chemical oxygen demand fractions of municipal wastewater

Table 1: Summary of COD fractions of raw wastewater (literature data)

\begin{tabular}{|c|c|c|c|c|c|c|c|c|}
\hline $\begin{array}{l}\text { Country, } \\
\text { region }\end{array}$ & $\begin{array}{l}\mathrm{S}_{\mathrm{I}} \\
\% \\
\end{array}$ & $\begin{array}{l}\mathrm{S}_{\mathrm{S}} \\
\% \\
\end{array}$ & $\begin{array}{l}X_{I} \\
\% \\
\end{array}$ & $\begin{array}{l}\mathrm{X}_{\mathrm{S}} \\
\% \\
\end{array}$ & $\begin{array}{l}X_{H} \\
\% \\
\end{array}$ & $\begin{array}{l}\mathrm{X}_{\mathrm{S}}\left(+\mathrm{X}_{\mathrm{H}}\right)^{* *} \\
\%\end{array}$ & $\begin{array}{l}\text { VFA } \\
\%\end{array}$ & References \\
\hline N. America & 10.5 & 14.1 & 27.9 & & & 44.3 & 0.0 & Hydromantis, 2007 \\
\hline S. Africa & 5.0 & 20.0 & 13.0 & & & 62.0 & & Ekama et al., 1986 \\
\hline Switzerland & 14.0 & 9.0 & 9.0 & 56.0 & 12.0 & 68.0 & & Kappeler and Gujer, 1992 \\
\hline Denmark & 2.0 & 20.0 & 18.0 & 40.0 & 20.0 & 60.0 & & Henze, 1992 \\
\hline Sweden & 15.0 & 27.0 & 17.0 & 33.0 & 8.0 & 41.0 & & Xu and Hultman, 1996 \\
\hline Denmark & 7.6 & 20.3 & 13.0 & 51.5 & 7.2 & 58.7 & 8.1 & Gernaey and Jorgensen, 2004 \\
\hline Denmark & 5.0 & 35.0 & 10.0 & 35.0 & 15.0 & 50.0 & & Chachaut et al., 2005 \\
\hline N. America & $12.0 *$ & 15.0 & $14.5 *$ & & & 59.0 & 1.4 & Melcer et al., 2003 \\
\hline Netherlands & 6.0 & 26.0 & 39.0 & & & 28.0 & & Roeleveld and Loosdrecht, 2002 \\
\hline N. America & 5.0 & 16.0 & 13.0 & & & 66.0 & 2.4 & EnviroSim, 2005 \\
\hline France & 4.1 & 3.0 & 19.0 & & & 73.9 & & Marquot et al., 2006 \\
\hline Germany & 6.4 & 18.3 & 11.3 & 49.3 & 14.7 & 64.0 & & Wichern et al., 2003 \\
\hline Germany & 6.1 & 14.8 & 13.0 & 55.4 & 10.8 & 66.2 & & Wichern et al., 2001 \\
\hline Italy & 6.0 & 15.0 & 8.0 & 56.0 & 15.0 & 71.0 & & Carucci et al., 1999 \\
\hline Spain & 8.5 & 18.3 & 24.9 & 33.3 & 15.0 & 48.3 & & Del la Sota et al., 1994 \\
\hline Denmark & $10.0 *$ & $15.0 *$ & 20.0 & $40.0 *$ & 15.0 & $55.0 *$ & 8.8 & Henze, 1992 \\
\hline Switzerland & 4.0 & 10.0 & 20.0 & 54.1 & 11.9 & 66.0 & & Rieger et al., 2001 \\
\hline Average & 7.5 & 17.5 & 17.1 & 45.8 & 13.1 & 57.9 & 4.1 & \\
\hline
\end{tabular}

* Estimate based on the article; ** Biomass COD is included in the slowly biodegradable substrate fraction

Table 2: Summary of COD fractions of primary wastewater (literature data)

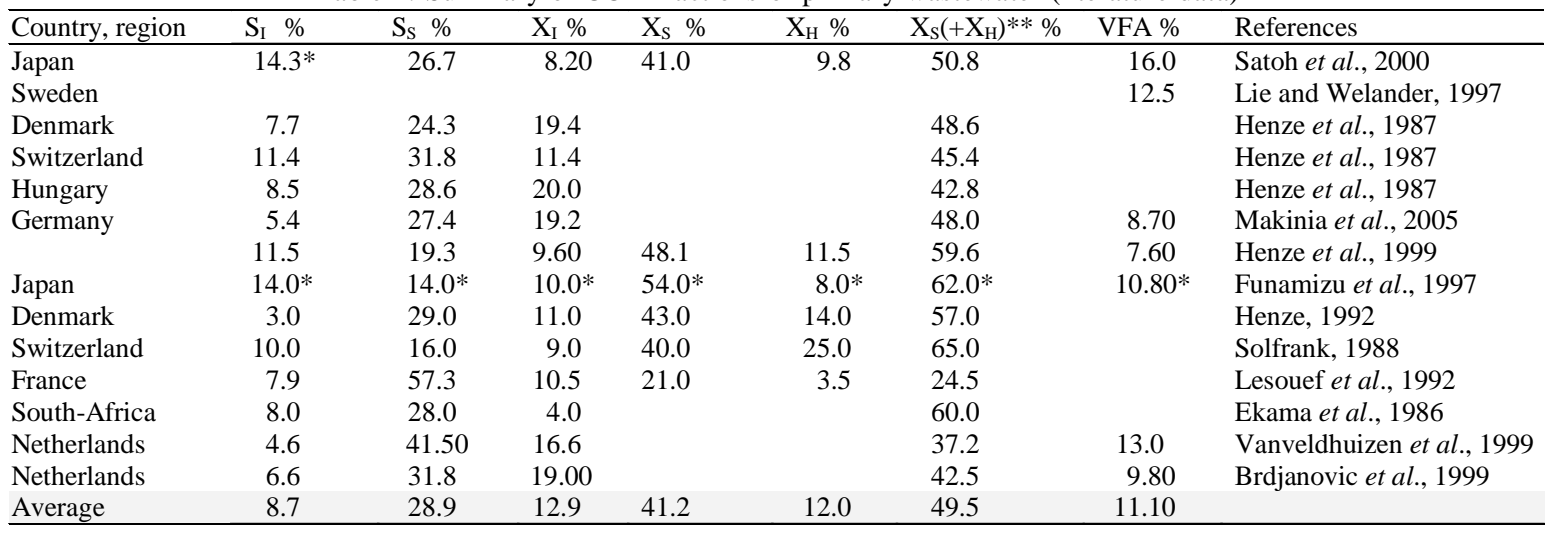

* Estimate based on the article; ** Biomass COD is included in the slowly biodegradable substrate fraction

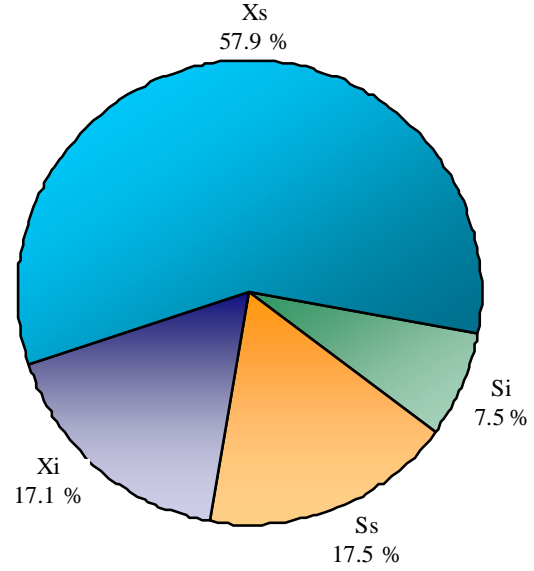

Fig. 2: Average COD fractions of raw sewage according to literature data

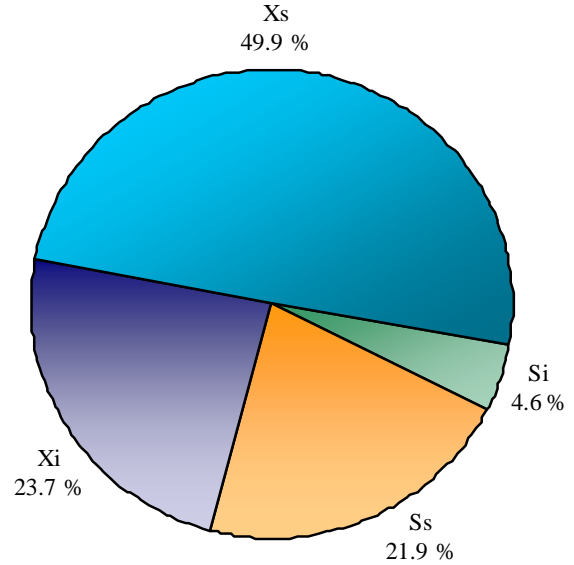

Fig. 3: Average COD fractions of raw wastewater based on Hungarian measurements 
Table 3: COD fractions of Hungarian raw wastewater (experimental results)

\begin{tabular}{|c|c|c|c|c|c|c|}
\hline WWTP & $\mathrm{COD}_{\text {тот }}(\mathrm{mg} / \mathrm{L})$ & $\mathrm{S}_{\mathrm{I} \%}$ & $\mathrm{~S}_{\mathrm{S} \%}$ & $\mathrm{X}_{\mathrm{I} \%}$ & $\mathrm{X}_{\mathrm{S}}\left(+\mathrm{X}_{\mathrm{H}}\right) * *$ & VFA \\
\hline Harskut & 987.0 & 5.7 & 20.4 & 16.5 & 57.5 & 2.9 \\
\hline Liter & 443.0 & 5.3 & 17.3 & 12.6 & 64.8 & 0.0 \\
\hline Nagyvazsony & 765.0 & 3.3 & 20.0 & 29.4 & 47.3 & 7.1 \\
\hline Bakonybel & 1092.0 & 2.4 & 27.3 & 32.5 & 37.9 & \\
\hline Borzavar & 1362.0 & 3.2 & 26.8 & 22.1 & 48.0 & \\
\hline Dudar* & 867.0 & 6.5 & 13.0 & 32.3 & 48.2 & \\
\hline Padrag & 582.0 & 10.8 & 10.0 & 24.4 & 54.8 & \\
\hline Epleny & 977.0 & 2.1 & 25.4 & 31.1 & 41.4 & \\
\hline Szapar & 665.0 & 5.4 & 30.4 & 28.3 & 35.9 & \\
\hline Zirc* & 280.0 & 3.9 & 10.1 & 20.6 & 65.5 & \\
\hline Veszprem & 490.0 & 2.2 & 40.7 & 11.1 & 46.1 & 15.8 \\
\hline Min. & 280.0 & 2.1 & 10.0 & 11.1 & 35.9 & 0 \\
\hline Max & 1362.0 & 10.8 & 40.7 & 32.5 & 65.5 & 15.8 \\
\hline Max & 773.6 & 4.6 & 21.9 & 23.7 & 49.8 & 6.5 \\
\hline
\end{tabular}

of some countries. For example, Dutch wastewater contains high $\mathrm{X}_{\mathrm{I}}$, Swiss sewage has high $\mathrm{S}_{\mathrm{I}}$ and Hungarian wastewater has low $\mathrm{S}_{\mathrm{I}}$ ratio. However, such generalization is not warranted with scanty data.The high $\mathrm{X}_{\mathrm{I}}$ can be explained as due to the long hydraulic residence time in sewage pipelines where a significant portion of the substrate fraction, biologically degraded, increases the ratio of inert particulate components. Outstanding inert soluble COD fraction in the sewage of large developed cities may be the result of industrial wastewater discharges. The differences between primary and raw wastewater COD fractions are along the expected lines; the soluble fractions $\left(S_{\mathrm{I}}+S_{\mathrm{S}}\right)$ in primary sewage are higher while particulate fractions $\left(X_{\mathrm{S}}+X_{\mathrm{I}}\right)$ are lower than in raw wastewaters. However, the decrement of suspended fraction and the increment of soluble fraction after clarification were very little that is only $12.5 \%$. The total substrate fraction $\left(X_{\mathrm{s}}+\right.$ $S_{\mathrm{S}}$ ) is $3 \%$ higher in primary wastewater than in raw sewage. This implies that the settling properties of biodegradable fractions are worse than those of the inert components. This is because the slowly biodegradable substrate $\left(X_{\mathrm{s}}\right)$ has always some unabsorbed colloidal fraction that can not be settled in the primary clarifier. The Hungarian wastewater samples had, on the average $8 \%$ lower $\mathrm{X}_{\mathrm{S}}$ and $6.6 \%$ higher $X_{1}$ than the corresponding averages of literature data and this may result in increasing the aeration needs and sludge production of the WWTP (Figs. 2 and 3). However, the most interesting result is the relatively low (4.6\%) inert soluble fraction of the Hungarian samples as compared to the average of $7.5 \%$ in the literature. If the influent total COD concentration in Hungarian wastewater is above $1000 \mathrm{mg} / \mathrm{L}$ (typical in Hungarian rural areas), then the WWTPs may have difficulties to achieve the desired discharge limits (e.g.: $50 \mathrm{mg} / \mathrm{L}$ ) in spite of the relatively low inert soluble fraction.

\section{ACKNOWLEDGMENTS}

The financial support of the Department of Environmental Engineering and Chemical Technology at Pannonia University is gratefully acknowledged.

\section{REFERENCES}

Brdjanovic, D.; Van Loosdrecht, M. C. M.; Versteeg, P.; Hooijmans, C. M; Alaerts, G. J.; Heijnen, J. J., (2000). Modeling COD, $\mathrm{N}$ and $\mathrm{P}$ removal in a full-scale WWTP Haarlem Waarderpolder., Water Res., 34 (3), 846-858.

Carucci, A.; Rolle, E.; Smurra, P., (1999). Management optimization of a large wastewater treatment plant., Water Sci. Tech. 39 (4), 129-136.

Chachaut, B; Roche, N.; Latifi, R., (2005). Long-term aeration strategies for small-size alternating activated sludge treatment plants., Chem. Eng. Prog., 44 (5), 591-604.

Del la Sota, A.; Larrea, L.; Novak, L.; Grau, P.; Henze, M., (1994). Performance and model calibration of R-D-N processes in pilot plant., Water Sci. Tech. 30 (6), 355-364.

Ekama, G. A.; Dold, P. L.; Marais, G. V. R., (1986). Procedures for determining influent COD fractions and the maximum specific growth rate of heterotrophs in activated sludge systems., Water Sci. Tech., 18 (6), 91-114.

EnviroSim Assiocates Ltd., (2005). BioWin 2.1. simulator default parameters.

Funamizu, N.; Yamamoto, S.; Kitagawa, Y.; Takakuwa, T., (1997). Simulation of the operational conditions of the fullscale municipal wastewater treatment plant to improve the performance of nutrient removal., Water Sci. Tech. 36 (12), 9-18.

Gernaey, K. V.; Jorgensen, S. B., (2004). Benchmarking combined biological phosphorous and nitrogen removal wastewater treatment plant processes., Cont. Eng. Pract. 12 (3), 357373.

Henze, M., (1992). Characterization of wastewater for modelling of activated sludge processes., Water Sci. Tech., 25 (6), 1-5.

Henze, M.; Grady, C. P. L.; Gujer, W.; Marais, G. V. R.; Matsuo, 
T., (1987). Activated sludge model No. 1. IAWPRC Scientific and Technical Report 3. London: IAWPRC.

Henze, M.; Gujer, W.; Mino, T.; Matsuo, T.; Wentzel, M. C.; Marais, G. V. R., (1995). Activated sludge model No. 2. IAWQ Scientific and Technical Report No. 3., London: IAWQ.

Henze, M.; Gujer, W.; Mino, T.; Matsuo, T.; Wentzel, M. C.; Marais, G. V. R.; van Loosdrecht, M. C. M., (1999). Activated sludge model No. 2d., Water Sci. Tech. 39 (1) 165-182.

Henze, M., Gujer, W., Mino, T., van Loosdrecht, M., (2000). Activated sludge model No. 3. Activated sludge models ASM1, ASM2, ASM2D and ASM3, in: Henze M.; Gujer, W.; Mino, T.; Van Loosdrecht, M., (Eds.). IWA Scientific and Technical Report No. 9. London: IWA.

Hydromantis Ltd., (2007). GPS-X 5.0 software. General Purpose Simulator - default parameters.

Kappeler, J.; Gujer W., (1992). Estimation of kinetic parameters of heterotrophic biomass under aerobic conditions and characterization of wastewater for activated sludge modelling., Water Sci. Tech. 25 (6), 125-139.

Lesouef, A.; Payraudeau M.; Rogalla, F.; Kleiber, B., (1992). Optimizing nitrogen removal reactor configuration by onsite calibration of the IAWQ activated sludge model., Water Sci. Tech., 25 (6), 105-123.

Lie, E.; Welander, T., (1997). A method for determination of the readily fermentable organic fraction in municipal wastewater., Water Res., 31 (6), 1269-1274.

Makinia, J.; Rosenwinkel, K. H.; Spering, V., (2005). Longterm simulation of the activated sludge process at the HanoverGrümmerward pilot WWTP., Water Res., 39 (8), 1489-1502.

Mamais, D.; Jenkins, D.; Pitt, P., (1993). A rapid physico-cemical method for the determination of readily biodegradable soluble COD in municipal wastewater., Water Res., 27 (1), 195-197.

Marquot, A.; Stricker, A. E.; Racault, Y., (2006). ASM1 dynamic calibration and long term-validation for an intermittently aerated WWTP., Water Sci. Tech. 53 (12), 247-256.

Melcer, H.; Dold, P. L.; Jones, R. M.; Bye, C. M.; Takacs, I.; Stensel, H. D.; Wilson, A. W.; Sun, P.; Bury, S., (2003). Methods for wastewater characterisation in activated sludge modelling. Water Environment Research Foundation (WERF), Alexandria, VA, USA.

Rieger, L.; Koch, G.; Khüni, M.; Gujer, W.; Siegrist, H., (2001).
The EAWAG BIO-P module for activated sludge model No. 3., Water Res., 35 (16), 3887-3903.

Roeleveld, P. J.; Van Loosdrecht, M. C. M., (2002). Experience with guidelines for wastewater characterisation in The Netherlands., Water Sci. Tech., 45 (6), 77-87.

Satoh, H.; Okuda, E.; Mino, T.; Matsuo, T., (2000). Calibration of kinetic parameters in the IAWQ activated sludge model: a pilot scale experience., Water Sci. Tech., 42 (3-4), 29-34

Sin, G.; Van Hulle, S. W. H.; Dirk, J. W.; Pauw, D.; Van Griensven, A.; Vanrollleghem, P. A., (2005). A critical comparison of systematic calibration protocols for activated sludge models: A SWOT analysis., Water Res., 39 (12) 2459-2474.

Sollfrank, U., (1988). Bedeutung organischer Fraktionen in kommunalem Abwasser im Himblick auf die mathematische modellierung von belebtschlammsystemen. Dissertation der ETH, Zürich, Schweiz, No. 8765.

Spanjers, H.; Vanrolleghem, P., (1995). Respirometry as tool for rapid characterization of wastewater and activated sludge., Water Sci. Tech., 31 (2), 105-114.

Vanrolleghem, P. A.; Insel, G.; Petersen, B.; Sin, G.; De Pauw, D.; Nopens, I.; Weijers, S.; Gearnaey, K., (2003). A comprehensive model calibration procedure for activated sludge models. In Proceedings: WEFTEC $76^{\text {th. }}$ Annual Conference and Exhibition, Los Angeles, CA, USA.

Vanveldhuizen, H. M.; Van Loosdrecht, M. C. M.; Heijnen, J. J., (1999). Modelling Biological Phosphorous and nitrogen removal in a full scale activated sludge process., Water Res. 33 (16), 3459-3468.

Wichern, M.; Lübken, M.; Blömer, R.; Rosenwinkel, K. H., (2003). Efficiency of the activated sludge model No. 3 for German wastewater on six different WWTPs., Water Sci. Tech., 47 (11), 211-218.

Wichern, M.; Obenaus, F.; Wulf, P.; Rosenwinkel, K. H., (2001). Modelling of full-scale wastewater treatment plants with different treatment processes using the activated sludge model No. 3., Water Sci. Tech., 44 (1), 49-56.

Xu, S.; Hultman, B., (1996). Experiences in wastewater characterization and model calibration for the activated sludge process., Water Sci. Tech., 33 (12), 89-98.

\section{AUTHOR (S) BIOSKETCHES}

Pasztor, I., M.Sc. student at Department. of Environmental Engineering and Chemical Technology, University of Pannonia, Veszprem, Hungary. Email: fapipa@yahoo.com

Thury, P., M.Sc. student at Department. of Environmental Engineering and Chemical Technology, University of Pannonia, Veszprem, Hungary. Email: thuryp@almos.vein.hu

Pulai, J., M.Sc. student at Department. of Environmental Engineering and Chemical Technology, University of Pannonia, Veszprem, Hungary. Email: pulaijudit@freemail.hu

\footnotetext{
This article should be referenced as follows:

Pasztor, I.; Thury, P., Pulai, J., (2008). Chemical oxygen demand fractions of municipal wastewater for modeling wastewater treatment. Int. J. Environ. Sci. Tech., 6 (1), 51-56.
} 